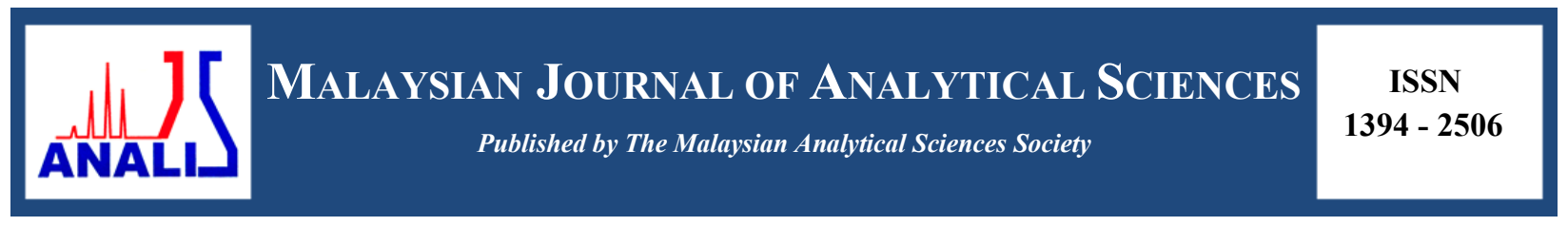

\title{
ASSESSMENT OF ANTIOXIDANT ACTIVITY AND TOTAL PHENOLIC CONTENT FROM GREEN COFFEE Robusta Sp. BEANS
}

\section{(Penilaian Aktiviti Antioksidan dan Kandungan Jumlah Fenolik dari Biji Kopi Robusta Sp. Hijau)}

\author{
Raseetha Siva $^{1 *}$, Noratikah Rajikin ${ }^{1}$, Zaibunnisa Abdul Haiyee ${ }^{1}$, Wan Iryani Wan Ismail ${ }^{2}$ \\ ${ }^{1}$ Faculty of Applied Sciences, \\ Universiti Teknologi MARA, 40450 Shah Alam, Selangor, Malaysia \\ ${ }^{2}$ School of Fundamental Sciences, \\ Universiti Malaysia Terengganu, 21030 Kuala Terengganu, Terengganu, Malaysia \\ *Corresponding author: raseetha@salam.uitm.edu.my
}

Received: 17 August 2015; Accepted: 23 August 2016

\begin{abstract}
Methanol and isopropanol were used as extraction solvent to determine the percentage yield of chlorogenic acid (CGA) in green Robusta (Coffea canephora) coffee bean. CGA was extracted by using isolation method with activated carbon to trap the CGA content from the complex compounds in green coffee beans. Results indicated that percentage yield of CGA extracted by using isopropanol was significantly higher (5.21\%) compared to methanol (4.55\%). Besides, antioxidant activity and total phenolic content were also analyzed. From this study, isopropanol extracted more antioxidant activity and total phenolic content as compared to methanol. For antioxidant activity, isopropanol and methanol extracted $0.48 \mathrm{mg}$ and $0.15 \mathrm{mg}$ of Fe (II) per gram of dry sample, respectively. For total phenolic content, isopropanol and methanol extracted $30.65 \mathrm{mg}$ and $16.26 \mathrm{mg}$ of gallic acid per gram of dry sample, respectively. Isopropanol extraction with ratio 60:40 (isopropanol: water) conserved more CGA content than methanol which was analyzed using high performance liquid chromatography. Chromatogram showed that the retention time of CGA is at 4.68 minutes which is similar to the retention time of standard CGA.
\end{abstract}

Keywords: green coffee bean, antioxidant, phenolic, methanol, isopropanol

\section{Abstrak}

Metanol dan isopropanol telah digunakan sebagai pelarut ekstrak untuk menentukan peratusan hasil asid klorogenik (CGA) di dalam biji kopi hijau Robusta (Coffea canephora). CGA diekstrak dengan menggunakan kaedah pengasingan dengan karbon teraktif berfungsi sebagai perangkap kandungan CGA daripada sebatian kompleks di dalam biji kopi hijau. Keputusan hasil peratusan CGA yang diekstrak oleh isopropanol adalah secara signifikan lebih tinggi (5.21\%) berbanding metanol (4.55\%). Selain itu, aktiviti antioksidan dan jumlah kandungan fenolik juga telah dianalisis. Daripada kajian ini, pelarut isopropanol mengekstrak lebih banyak aktiviti antioksidan dan jumlah kandungan fenolik berbanding pelarut metanol. Bagi penentuan aktiviti antioksidan isopropanol dan metanol berupaya mengekstrak masing - masing $0.48 \mathrm{mg}$ dan $0.15 \mathrm{mg}$ Fe (II) bagi setiap gram sampel kering. Bagi penentuan jumlah kandungan fenolik, isopropanol dan metanol mengekstrak $30.65 \mathrm{mg}$ dan $16.26 \mathrm{mg}$ asid gallic bagi setiap gram sampel kering. Pengekstrakan isopropanol dengan nisbah 60:40 (isopropanol: air) memelihara lebih kandungan CGA daripada metanol yang dianalisa menggunakan kromatografi cecair prestasi tinggi. Kromatogram menunjukkan bahawa masa tahanan CGA adalah pada 4.68 minit selari dengan masa tahanan larutan piawai CGA.

Kata kunci: biji kopi hijau, antioksidan, fenolik, metanol, isopropanol 


\section{Raseetha et al: ASSESSMENT OF ANTIOXIDANT ACTIVITY AND TOTAL PHENOLIC CONTENT FROM GREEN COFFEE Robusta Sp. BEANS}

\section{Introduction}

Overweight or obesity becomes common contributing factors of many unnecessary diseases, such as diabetes mellitus, high blood pressure and cancer. Common causes of the disease are usually due to wrong diet and lack of physical activity [1]. A latest survey in Japan reveals that occurrence of diabetes mellitus is increasing. Furthermore, International Obesity Taskforce (IOTF) reported that up to 1.7 billion people all over the world could eventually be exposed to weight-related health risks [2]. Since these health problems create a big economic impact on health care system in the world, health food supplements are now quite popular among weight observant. Recently, chitosan and citrus (Citrus aurantium) fruits are some of the food supplements for weight loss which helps in reduce fat absorption and breaking down fat respectively. Additionally, it has been identified that coffee bean extract releases chlorogenic acid as an inhibitor for the production of glucose in liver and promote insulin secretion [3]. Therefore, further study on chlorogenic acid as weight loss agent can be explored.

Chlorogenic acid (CGA) as shown in Figure 1 belongs to a family of ester consist of caffeic acid and quinic acid [4]. The melting and boiling point of CGA is $205-209^{\circ} \mathrm{C}$ and $665^{\circ} \mathrm{C}$ at $760 \mathrm{mmHg}$, respectively. It is known that CGA solubilizes in ethanol, dimethylsulfoxide and dimethylformamide. Chlorogenic acid is well known as a natural antioxidant that has properties of retarding the oxidation of food products which help keeps the fresh flavor and nutritional value for longer time. This antioxidant also reduces the release of glucose into the bloodstream after a meal [5]. The current commercial source of chlorogenic acid is green coffee beans. It was found that coffee pulp contains natural antioxidants like hydroxycinnamic acids [6].



Figure 1. Chemical structure of chlorogenic acid (CGA)

Green coffee beans are basically the seeds from the fruit of coffee trees. The two main green coffee beans that are commonly produced and sold are Arabica coffee (Coffea arabica) and Robusta coffee (Coffea canephora) [7]. Moreover, coffee is well known as a good source of antioxidant [8]. Coffee also rich with antioxidants and contain of flavonoids. The presence of antioxidant will slow or prevent the oxidation of other chemical. Oxidation can be simplified as gain of oxygen and loss of electron. On the other hand, antioxidants may be either present in two forms which are natural antioxidants and synthetic antioxidants. Natural antioxidants include flavonoids, phenolic, tocopherols (Vitamin E) and also ascorbic acid. About the caffeine and chlorogenic acid content, Arabica generally has less amount of caffeine which is approximately $1.2 \%$ and 5.5 to $8.0 \%$ of chlorogenic acid while Robusta has $2.2 \%$ of caffeine and $7.0-10.0 \%$ of chlorogenic acid [9]. The post-harvest processing gives effect on the chemical composition of coffee seeds especially in water-soluble components like sugar, caffeine, trigonellie and chlorogenic acid [9].

Nowadays, the worldwide consumption of coffee is increasing in popularity due to their health benefits. These benefits appear to be effected by their antioxidant activity. Antioxidant is a substance that protects living tissues against damage caused by free radicals. Free radicals are species produced during aerobic respiration due to the incomplete reduction of oxygen molecule and directly related to various diseases such as cancer, cardiovascular, inflammatory and neurogenerative pathologies are associated with oxidative stress [10]. Besides fruits and vegetables, plant beverages such as coffee brew have been proposed as an important source of antioxidant in human diet $[11,12]$. Additionally, phenolic compounds have an important role in nutritional, organoleptic and commercial 
properties of agricultural foodstuffs as they contributed to the sensory properties such as colour, astringency, bitterness and flavour of coffee, because of the interaction between phenolics, mainly procyanidin and glycoprotein in saliva [13].

Solvent extraction technique was used to extract chlorogenic acid from green coffee bean. For this solvent extraction, methanol and isopropanol was used to extract the chlorogenic acid and determine the yield extract. Activated carbon was used to extract the cholorogenic acid content in the filtered extraction [14]. Thus the aim of this study was to compare which solvent (isopropanol or methanol) gives better chlorogenic acid yield antioxidant activity and total phenolic content. Efficient solvent extraction information for antioxidant activity and total phenolic content in green coffee beans was also investigated.

\section{Chemicals}

\section{Materials and Methods}

Coffee canephora (Robusta coffee) was supplied from Teluk Gong, Klang, Malaysia. All the chemicals were of analytical grade. Folin-Ciocalteu, 3,4,5-trihydroxybenzoic acid (gallic acid), methanol (HPLC grade), acetic acid (HPLC grade) and isopropanol (HPLC grade) were purchased from Merck, Malaysia. The remaining chemicals were purchased from Systerm, Malaysia, listed as follows: Chlorogenic acid, 1,3,5-triazine,2,4,6-tri-2-pyridinyl (TPTZ), 2,2-diphenyl-1-picrylhydrazyl (DPPH), ascorbic acid and $\mathrm{FeCl}_{3} \cdot 6 \mathrm{H}_{2} 0$ (ferric chloride hexahydrate).

\section{Equipment's}

The water bath (Varian) for extraction of green coffee beans, UV-Vis spectrophotometer (Cary 50 model) and rotary evaporator to dry green coffee bean extract which is located in Universiti Teknologi MARA (UiTM) Shah Alam.

\section{Pre-treatment of samples}

Green coffee beans were washed thoroughly with tap water for several times to remove the remaining soil, dirt and contaminants such as tiny stones and other unnecessary particles. The green coffee beans were collected and grinded to form spent ground coffee. The samples were placed in sealed plastic bags and kept at $4{ }^{\circ} \mathrm{C}$ until needed for analysis.

\section{Solvent extraction of chlorogenic acid}

Solvent extraction was carried out according to previous method [15]. Approximately $10 \mathrm{~g}$ of spent ground coffee was weighed and loaded into glass column. The samples were extracted with selected solvent at samples to solvent ratio 1:10. Solvents mixture of either isopropanol or methanol with water in ratio 60:40 was used for extraction. An amount $100 \mathrm{~mL}$ of solvent was added into glass column and allowed it to stand over a period of 5 hours whereas for the methanol water mixture, it was allowed to stand over 24 hours. The activated carbon was used to extract chlorogenic acid content in the filtered extract. The extract was drained and distilled on rotary evaporator at $50{ }^{\circ} \mathrm{C}$ under reduced pressure ( 40 millibar) and the product was freeze dried and stored at room temperature prior to analysis.

\section{Determination of chlorogenic Acid}

The High Performance Liquid Chromatography (HPLC) analysis was performed by using Agilent Technologies 1200 Series (Santa Clara, California, United States) with diode-array detector (DAD) equipped with LiChroCART $250 \mathrm{~mm}$ x $4.6 \mathrm{~mm}$ i.d. Eclipse Puresper STAR RP-C18 column (5 $\mu \mathrm{m})$ (Merck, United States), using a binary solvent system: Solvent A, water-acetic acid, 97:3 (v/v); solvent B, methanol and reverse phase. A program of gradient to $100-90 \%$ A from $0-10$ minutes, $90-30 \%$ A for $10-32$ minutes, $30-0 \%$ A from $32-45$ minutes at a flow rate of $1.0 \mathrm{ml} / \mathrm{min}$ was used at a wavelength of $320 \mathrm{~nm}$. The sample volume is $20 \mu \mathrm{L}$ injected into HPLC. An amount $50 \mathrm{ppm}$ of CGA standard was prepared in order to calculate the response factor, $\mathrm{R}_{\mathrm{f}}$ for the standard using the following formula adapted from Aishah et al. [16] (equation 1):

$$
\text { Response Factor, } R_{f}=\frac{\text { amount }}{\text { area }}
$$

The amount of CGA present in the sample was then compared to the standard CGA using the calculated $\mathrm{R}_{\mathrm{f}}$. 


\section{Raseetha et al: ASSESSMENT OF ANTIOXIDANT ACTIVITY AND TOTAL PHENOLIC CONTENT FROM GREEN COFFEE Robusta Sp. BEANS}

\section{Ferric reducing antioxidant power (FRAP)}

The FRAP assay was conducted according to method described previously [17]. The FRAP reagent were prepared by mixing acetate buffer $(0.3 \mathrm{~mol} / \mathrm{L})$, TPTZ $(10 \mathrm{mmol} / \mathrm{L})$ and $\mathrm{FeCl}_{3} \cdot 6 \mathrm{H}_{2} 0(20 \mathrm{mmol} / \mathrm{L})$ in the ratio $10: 1: 1$. FRAP reagent were prepared as required by mixing $25 \mathrm{~mL}$ acetate buffer, $2.5 \mathrm{~mL}$ TPTZ solution, and $2.5 \mathrm{~mL} \mathrm{FeCl} \mathrm{F}_{3} \cdot 6 \mathrm{H}_{2} \mathrm{O}$ solution. For a volume of $100 \mu \mathrm{L}$ of the coffee extract, $3.0 \mathrm{~mL}$ of the FRAP reagent was added to test tubes with stoppers and the mixture was then left at rest in dark for $30 \mathrm{~min}$ at $37{ }^{\circ} \mathrm{C}$. The absorbance of blue colouration was measured against a blank sample at a wavelength of $593 \mathrm{~nm}$, using a UV-Vis spectrophotometer. The calibration curve was prepared using standard solutions of ferrous sulphate at concentration of $0.5-2.5 \mathrm{mmol} / \mathrm{L}$. All of the measurements were conducted in triplicate and the results were expressed in $\mathrm{mmol} \mathrm{Fe}^{2+}$ per litre sample.

\section{Determination of total phenolic content using Folin-Ciocalteu reagent}

Total phenolic content in spent ground coffee was determined by using the Folin-Ciocalteu reagent according to the colorimetric method described previously [18]. Approximately $2 \mathrm{~mL}$ of filtered extract will be mixed with $30 \mathrm{~mL}$ of sodium carbonate solution at $7.5 \%(\mathrm{w} / \mathrm{v})$ and $7.5 \mathrm{~mL}$ of Folin-Ciocalteu reagent. Subsequently, $200 \mu \mathrm{L}$ of distilled water was added and the solution was mixed. After that, the mixture was heated at $60{ }^{\circ} \mathrm{C}$ for 5 minutes and allowed to cool at room temperature. The absorbance was measured by using spectrophotometer at $700 \mathrm{~nm}$. A calibration curve was made from gallic acid standard solution $(100,150,200,250$ and $300 \mathrm{mg} / \mathrm{L})$ and the blank was prepared with distilled water. The total phenolic content was expressed as milligram gallic acid equivalent (GAEs) per dry weight material.

\section{Statistical analysis}

The results for extraction yield, antioxidant assays and total phenolic determination were expressed as mean \pm standard deviation $(n=3)$. All data were analyzed by one-way analysis of variance (ANOVA) followed by Tukey's multiple comparison test. The level of significance was limited at $p<0.05$.

\section{Results and Discussion}

Assessment of percentage yield and retention times of chlorogenic acid

Solvent extraction method was used to extract chlorogenic acid in green coffee bean which involved two different types of solvent, methanol and isopropanol. Each solvent was mixed with water with ratio of 60:40, respectively. Activated carbon was used to isolate the chlorogenic acid content.

Table 1 shows the percentage yield, concentration and appearance of chlorogenic acid. From the results, the extraction of chlorogenic acid by using methanol was $4.55 \%$ (2.28 ppm) while isopropanol was $5.21 \%$ (2.61 ppm). The results indicated that the isopropanol solvent extracted significantly higher yield as compared to methanol solvent. This finding is also consistent with previous reports. Chlorogenic acid yield preserved by using isopropanol was about $27 \%$ in a ratio of $60: 40$ as reported previously [15]. The chlorogenic acid yield from green coffee beans using methanol and isopropanol solvent were $4.67 \%$ and $5.28 \%$ respectively [14]. The mixture of isopropanol and water (60:40) used in this study increased the strength for extracting bioactive compounds such as chlorogenic acid. Attributable to polar nature of isopropanol, the yield of chlorogenic acid generally increases in those solvent, which are isolated using activated carbon [19]. It is widely accepted that higher concentration of phenolic compounds increases antioxidant activity, thus correlating to higher CGA yield $[15,20]$.

Table 1. Percentage yield, concentration and appearance of chlorogenic acid

\begin{tabular}{lccl}
\hline Type of Solvent & $\begin{array}{c}\text { \% Yield of } \\
\text { Chlorogenic Acid }\end{array}$ & $\begin{array}{c}\text { Concentration } \\
\text { (ppm) }\end{array}$ & Appearance \\
\hline Methanol & $4.55^{\mathrm{b}} \pm 0.18$ & $2.28^{\mathrm{b}} \pm 0.18$ & Light green \\
Isopropanol & $5.21^{\mathrm{a}} \pm 0.68$ & $2.61^{\mathrm{a}} \pm 0.68$ & Light green \\
\hline
\end{tabular}

Means with different letters were significantly different at $\mathrm{p}<0.05$ 
The characterization of chlorogenic acid was conducted to determine retention time of chlorogenic acid standard and sample. Based on the Figure 2a, chromatogram of the standard chlorogenic acid (50 ppm) indicates the retention time at 4.68 minutes. Meanwhile, Figure $2 \mathrm{~b}$ shows the peak of chlorogenic acid content in green coffee beans. Based on the results, the chromatogram shows the retention time of chlorogenic acid at 4.68 minutes which was similar to the standard of chlorogenic acid. From the results, it is worthy to point that the isolation using activated carbon is suitable to trap the chlorogenic acid from a complex medium such as green coffee beans.

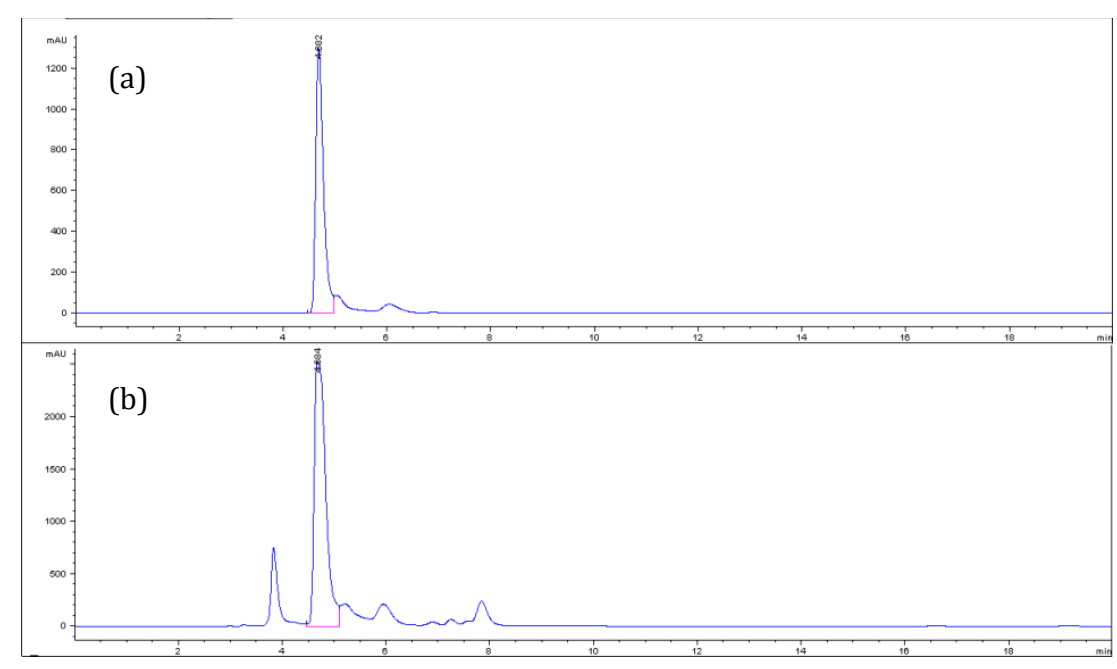

Figure 2. Chromatogram of (a) standard chlorogenic acid (50 ppm) and (b) green coffee beans

\section{Assessment of antioxidant properties and total phenolic content}

Table 2 shows the antioxidant activity found in green coffee beans expressed as mg Fe (II) per g dry sample. From the results, the antioxidant activity extracted by methanol solvent was $0.15 \pm 0.07$. Besides that, the extraction using isopropanol solvent was $0.48 \pm 0.19$. The antioxidant activity extracted by methanol solvent in spent coffee grounds was $0.109 \mathrm{mg} \mathrm{Fe}(\mathrm{II}) / \mathrm{g}$ dry sample [21].

Table 2. Antioxidant activity of green coffee beans

\begin{tabular}{lc}
\hline Type of solvent & in $\mathbf{~ m g ~ F e ~ ( I I ) / ~} \mathbf{g}$ dry sample \\
\hline Methanol & $0.15^{\mathrm{b}} \pm 0.07$ \\
Isopropanol & $0.48^{\mathrm{a}} \pm 0.19$ \\
\hline \multicolumn{2}{l}{ Means with different letters were significantly different at $\mathrm{p}<0.05$}
\end{tabular}

Meanwhile, Table 3 shows the results on total phenolic content found in green coffee beans. Total phenolic content extracted by isopropanol was significantly higher (30.65 mg GAE/g dry sample) as compared to extraction carried out using methanol (16.26 mg GAE/g dry sample). The total polyphenol conserved by methanol extraction was $16.00 \mathrm{mg} \mathrm{GAE} / \mathrm{g}$ dry sample [21]. Other than that, the total phenolic content conserved by isopropanol solvent is $31.71 \mathrm{mg} \mathrm{GAE} / \mathrm{g}$ dry sample [15]. Here again, the isopropanol ratio with water (60:40) extract of green coffee bean showed higher activity as compared to methanol extracts [15]. 
Table 3. Total phenolic content in green coffee beans

\begin{tabular}{lc}
\hline Type of solvent & in mg of GAE/g dry sample \\
\hline Methanol & $16.26^{\mathrm{b}} \pm 0.59$ \\
Isopropanol & $30.65^{\mathrm{a}} \pm 0.44$ \\
\hline \multicolumn{2}{l}{ Means with different letters were significantly different at $\mathrm{p}<0.05$}
\end{tabular}

Extraction solvent plays an important factor that affects the antioxidant capacity and total phenolic content in food materials. Vitamin $\mathrm{E}$ and oryzanol that has distinctive antioxidant activities extracted using isopropanol has more yield compared with using hexane as extraction solvent [22]. Isopropanol extract has comparatively higher amount of antioxidant due to the possibility of more polar phenolic compounds and lipids contained in the extract [20]. Antioxidants are extremely crucial in coffee beans to minimize the release of reactive oxygen species (ROS). If production of ROS exceeds the capacity of antioxidant systems, damage to sub-cellular compartments occurs, leading to cell destruction [23]. Hence it is important to maintain the antioxidant and total phenolic pool so that the integrity of green coffee beans is not jeopardized. This would enable the usage of these extracts to be used as ingredients in pharmaceutical industry or as food supplement as CGA implies positive impact on slimming and weight loss.

\section{Conclusion}

Higher in percentage yield of chlorogenic acid was found when isopropanol (5.21\%) was used as extraction solvent compared to methanol (4.55\%) solvent with ratio with water at 60:40. Furthermore, the amount of chlorogenic acid present in green coffee beans has been analyzed by using High Performance Liquid Chromatography (HPLC) with the retention time at 4.68 minutes. Besides that, isopropanol solvent also conserved more antioxidant activity and total phenolic compound. The amount of antioxidant extracted from green coffee bean by using isopropanol was significantly higher $0.48 \mathrm{mg} \mathrm{Fe}$ (II)/dry sample compared to methanol $0.15 \mathrm{mg}$ Fe (II)/dry sample. Total phenolic content extracted by isopropanol was also significantly higher (30.65 mg GAE/dry sample) compared to methanol was $16.26 \mathrm{mg} \mathrm{GAE} /$ dry sample. The obtained data would be useful for further application of green coffee bean extracts as weight reducing agent in nutraceutical and food supplement industry.

The authors would like to thank the Research Acculturation Grant Scheme (RAGS) RAGS/1/2014/STWN03/UITM//2 from the Ministry of Higher Education Malaysia. We would also thank the facilities and assistance obtained from lab staff at Universiti Teknologi MARA during the completion of this research.

\section{References}

1. Surh, Y. J. (2003). Cancer chemoprevention with dietary phytochemicals. Nature Review, 3: 768 - 780.

2. Kumanyika, S., Jeffery, R. W., Morabia, A., Ritenbaugh, C. and Antipatis V. J. (2002). Report: Obesity prevention: The case for action. International Journal of Obesity, 26: 425 - 436.

3. Olthof, M. R., Hollman, P. C., Zock, P. L. and Katan, M. B. (2001). Consumption of high doses of chlorogenic acid, present in coffee or of black tea increseas plasma total homocysteine concentrations in humans. American Journal of Clinical Nutrition, 73 (3): $532-538$.

4. Clifford, M. N., Johnston, K. L., Knigh, S. and Kuhnert, N. (2003). Hierarchical scheme for LC-MSn identification of chlorogenic acids. Journal of Agricultural and Food Chemistry, 51 (10): 2900 - 2911.

5. Johnston, K. L., Clifford, M. N. and Morgan, L. M. (2003). Coffee acutely modifies gastrointestinal hormone secretion and glucose tolerance in humans: Glycemic effects of chlorogenic acid and caffeine. American Journal of Clinical Nutrition, 78 (4): 728 - 733.

6. Arellano-Gonzalez, M., A., Ramirez-Coronel., A., Torres-Mancera, T., Perez-Morales., G. G. and SaucedoCastaneda, G. (2011). Antioxidant activity of fermented and non-fermented coffee (Coffea Arabica) pulp extracts. Food Technology, 49, $374-378$. 
7. Hecimovic I, Belscak-Cvitanovic A., Horzic D. and Komes D (2011). Comparative study of polyphenols and caffeine in different coffee varieties affected by the degree of roasting. Journal of Food Chemistry, 129: 991 1000 .

8. Esquivel, P. and Jimenez, V. M. (2012). Functional properties of coffee and coffee by-products, Food Research International, 46 (2): $488-495$.

9. Garrett, R., Schwab, N. V., Cabral, E. C., Henrique, B. V. M., Ifa, D. R., Eberlin, M. N. and Rezende, C. M. (2014). Ambient mass spectrometry employed for direct analysis of intact Arabica coffee beans. Journal of the Brazilian Chemical Society, 25 (7): 1172 - 1177.

10. Dorea, J. and da Costa, T., (2005). Is coffee a functional food? British Journal of Nutrition, 93 (6): 773 - 782.

11. Pulido, R., Hernandez G., M. and Saura, C. F. (2003). Contribution of beverages to the intake of lipophilic and hydrophilic antioxidants in the Spanish diet. European Journal of Clinical Nutrition, 57 (10): 1275 - 1282.

12. Svilaas, A., Sakhi, A., Andersen, L., Svilaas, T., Strom, E. and Jacobs, D. (2004). Intakes of antioxidants in coffee, wine, and vegetables are correlated with plasma carotenoids in humans. The Journal of Nutrition, 134 (3): $562-567$.

13. Scalbert, A., Johnson, I. T. and Saltmarsh, M. (2005). Polyphenols: Antioxidant and beyond, American Journal of Clinical Nutrition, 81: 215S - 217S.

14. Mirna, L., Angelina, A., Gerardo, V., Oscar, G. and Pierre, M. C. (2014). Isolation of green coffee chlorogenic acid using activated carbon. Journal of Food Composition and Analysis, 33: 55 - 58.

15. Naidu, M., Sulochanamma, G., Sampathu, S. R. and Srinivas, P. (2008). Studies on extraction and antioxidant potential of green coffee, Food Chemistry, 107: $377-384$.

16. Aishah, B., Cheow, C. S. and Fadhilah, J. (2008). Instrumental analysis of food: practical manual for undergraduates. Universiti Teknologi MARA, pp. 22-24.

17. Benzie, I. F. and Strain, J. J. (1999). Ferric reducing/antioxidant power assay: Direct measure of total antioxidant activity of biological fluids and modified version for simultaneous measurement of total antioxidant power and ascorbic acid concentration. Methods in Enzymology, 299: 15 - 27.

18. Singleton, V. L. and Rossi, J. A. (1965). Calorimetry of total phenolic with phosphomoybdic-phosphoungstic acid reagents. American Journal of Enology and Viticulture, 16: $144-158$.

19. Roginsky, V. and Lissi, E. A., (2005). Review of methods to determine chain breaking antioxidant activity in food. Food Chemistry, 92: 235 - 254.

20. Zubair, M., Anwar, F. and Shahid, S. A. (2012). Effect of extraction solvents on phenolics and antioxidant activity of selected varieties of Pakistani rice (Oryza sativa L.). International Journal of Agriculture \& Biology, 14: $935-940$.

21. Mussatto, S. I., Ballesteros, L. F., Martins, S. and Teixeira, J. A. (2011). Extraction of antioxidant phenolic compounds from spent coffee grounds. Separation and Purification Technology, 83 (1): $173-179$.

22. Zaidel, D. N. A., Daud, N. S. M., Song, L. K., Muhamad, I. I. and Jusoh, Y. M. M. (2016). Antioxidant properties of rice bran oil from different varieties extracted by solvent extraction methods. Jurnal Teknologi (Sciences \& Engineering), 78 (6-12): $107-110$.

23. Davey, M. W., Van Montagu, M., Inzé, D., Sanmartin, M., Kanellis, A., Smirnoff, N., Benzie, I. J. J., Strain, J. J., Favell, D. and Fletcher, J. (2000). Plant L-ascorbic acid: Chemistry, function, metabolism, bioavailability and effects of processing. Journal of the Science of Food and Agriculture, 80(7): 825 -860.

24. Foyer, C. H. and Noctor, G. (2005). Oxidant and antioxidant signalling in plants: A Re-evaluation of the concept of oxidative stress in a physiological context. Plant, Cell and Environment, 28(8): 1056-1071. 